\title{
Immunotherapy Trials for Type 1 Diabetes: The Contribution of George Eisenbarth
}

\author{
Jay S. Skyler, MD, MACP, and Alberto Pugliese, MD
}

\begin{abstract}
Type 1 diabetes (T1D) results from the autoimmune destruction of pancreatic $\beta$-cells, and as such it should respond to immunotherapy. George Eisenbarth gave many significant contributions to this field. He has been involved at some level in most immunotherapy trials during the past three decades. He was among the pioneers who attempted immunotherapy approaches in patients with recent-onset T1D. In the early 1980s he began studying relatives of those with the disease, leading to the concept that T1D was a chronic autoimmune disease, in which islet autoimmune responses would silently destroy $\beta$ cells and cause progressive impairment of insulin secretion, years to months before a diagnosis was made. Consequently, he was one of the first to attempt immune intervention in people at high risk of T1D. Throughout his career he developed autoantibody assays and predictive models (which included metabolic testing and later genetics) to identify individuals at risk of T1D. He provided seminal intellectual contributions and critical tools for prevention trials. His focus on insulin as a critical autoantigen led to multiple prevention trials, including the Diabetes Prevention Trial-Type 1 (DPT-1), which studied both parenteral and oral insulin. In the DPT-1 Oral Insulin Trial, a cohort with higher levels of insulin autoantibodies was identified that appeared to have delayed disease progression. Type 1 Diabetes TrialNet is conducting a new trial to verify or refute this observation. Moreover, George identified and tested in the mouse small molecules that block or modulate presentation of a key insulin peptide and in turn prevent the activation of insulin-specific T-lymphocytes. Thus, we believe his greatest contribution is yet to come, as in the near future we should see this most recent work translate into clinical trials.
\end{abstract}

$\mathbf{T}$ HAT TYPE 1 DIABETES (T1D) was immune mediated began to gain credence with the publication in 1974 of two articles-one demonstrating islet cell autoantibodies (ICA) in patients with $\mathrm{T}^{1} \mathrm{D}^{1}$ and the other showing a relationship between human leukocyte antigen (HLA) and T1D. ${ }^{2}$ The seminal article crystallizing the concept of T1D as a progressive autoimmune disease (Fig. 1) was published by George Eisenbarth in 1986. ${ }^{3}$ Although the basic concepts articulated in that now classical article remain intact, George periodically updated the scheme to incorporate emerging concepts (Fig. 2). ${ }^{4-6}$

An immune-mediated disease should be beneficially impacted by immune modulation therapy. Thus, beginning in the 1970s, there were attempts to treat T1D with various immune interventions. ${ }^{7,8}$ Moreover, if the immune process indeed begins a long time prior to clinical disease onset, immune intervention should be able to interdict the disease process and prevent or delay clinical disease. ${ }^{9,10}$ George Eisenbarth was involved in several early studies, designed to alter the course of the disease, in both recent-onset T1D and for prevention of T1D.

One early study, in recent-onset T1D, evaluated short courses of immunotherapy and included nine patients treated with prednisone, six treated with the anti-thymocyte globulin ATGAM plus prednisone, and three treated with placebo. ${ }^{11}$ Both therapies altered T cells, and ATGAM patients had lower hemoglobin $\mathrm{A} 1 \mathrm{c}(\mathrm{HbA} 1 \mathrm{c})$ levels on lower insulin doses with two subjects able to discontinue insulin therapy for 8 months. Unfortunately, thrombocytopenia precluded further study of ATGAM.

In recent-onset diabetes, George was also involved in a study with an anti-CD5 immunotoxin in which an anti-CD5 monoclonal antibody was linked to the ricin A-chain. ${ }^{12}$ This seemed to preserve $\beta$-cell function, as evidenced by C-peptide, but was never advanced to a full-scale trial. This was the first study in T1D using a monoclonal antibody, and it would foretell many studies that would subsequently evaluate several different monoclonal antibodies in T1D.

Prevention trials were really the thing that motivated George the most, however. He was involved in several early pilot trials. One demonstrated that in two individuals prednisone could increase first-phase insulin secretion rate (FPIR) during an intravenous glucose tolerance test (IVGTT). ${ }^{13}$ In another small pilot study of only three subjects, oral nicotinamide failed to slow progression of disease, ${ }^{14}$ an observation

Diabetes Research Institute, University of Miami Miller School of Medicine, Miami, Florida. 


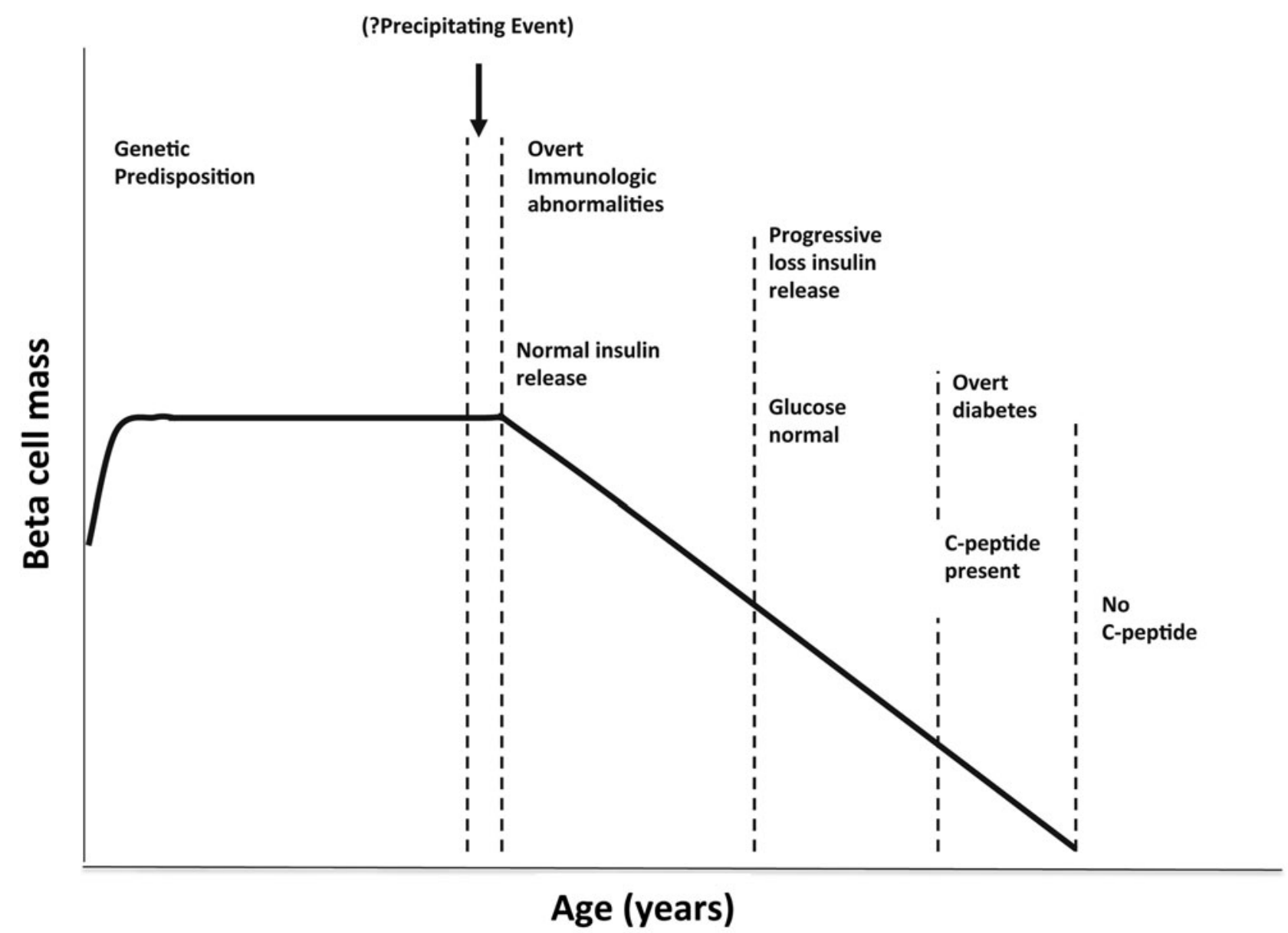

\section{Eisenbarth 1986}

FIG. 1. Scheme depicting a model of the stages of type 1 diabetes as a chronic progressive autoimmune disease, eventuating in "total" diabetes with absent $\beta$-cell function (i.e., no C-peptide production). The $x$-axis is without a specific time scale as the rate of progress of the disease may be quite variable. Modified from Eisenbarth. ${ }^{3}$ (Source: Eisenbarth GS: Autoimmune beta cell insufficiency - diabetes mellitus Type 1. Triangle 1984;23:111-124.)

that would presage the results of the large-scale multicenter European Nicotinamide Diabetes Intervention Trial (ENDIT) that involved 549 subjects at risk of developing T1D, which also did not show a benefit from nicotinamide. ${ }^{15}$

Building on the success in two large randomized controlled clinical trials of cyclosporine in improving outcomes in recentonset $\mathrm{T} 1 \mathrm{D},{ }^{16,17}$ it was logical to attempt using cyclosporine to prevent T1D. Therefore, in an early study in relatives at risk of T1D, six subjects treated with cyclosporine were compared with nine historical controls. ${ }^{18}$ The controls had developed T1D within 12 months (5.9 \pm 1.1 months), whereas four of the six cyclosporine-treated subjects developed T1D after 5, 24, 24 , and 47 months, respectively, and at the time of the report two cyclosporine-treated subjects had not yet developed T1D 47 and 57 months after entry into the study. Two of the subjects showed correction of their low FPIR levels.

Another early attempt at interrupting the T1D disease process in relatives at risk of the disease was to use insulin therapy itself. ${ }^{19}$ In a pilot study at the Joslin Diabetes Center, Boston, MA, George and his colleagues offered a program of insulin prophylaxis to 12 individuals at risk of T1D. Seven declined, and five accepted the treatment, which consisted of low-dose subcutaneous insulin therapy together with a 5-day course of intravenous insulin every 9 months. The subjects who declined were followed as a contemporary comparison group, and historical controls were analyzed as well. A life table analysis suggested a dramatic benefit, as after 3 years, only one of the five treated subjects had developed T1D, in comparison with all seven of those who had declined the therapy. ${ }^{19}$

Around the same time, Anette-G. Ziegler (a former Fellow of George's) and her colleagues in Munich, Germany, initiated a similar study of prophylactic insulin use. ${ }^{20}$ In their randomized trial, ultimately seven subjects at risk of T1D received prophylactic insulin, and seven were randomized to the control group. Life table analysis showed that clinical onset of T1D was delayed in the insulin-treated group compared with the control subjects (means \pm SEM diabetes-free survival, $5.0 \pm 0.9$ years vs. $2.3 \pm 0.7$ years; $P<0.03){ }^{21}$

The hypothesis that insulin therapy for relatives at risk of T1D was fully tested in the Diabetes Prevention Trial-Type 1 (DPT-1), a multicenter randomized clinical trial conducted through the National Institute of Diabetes and Digestive and Kidney Diseases (NIDDK). ${ }^{22}$ George was a member of the DPT-1 Steering Committee and was a member of the small group that designed the study. That design, in large part, was based on the Joslin pilot study ${ }^{19}$ and on concepts that George had articulated ${ }^{23}$ and required that subjects be positive for ICA and have either reduced FPIR during an IVGTT (as 


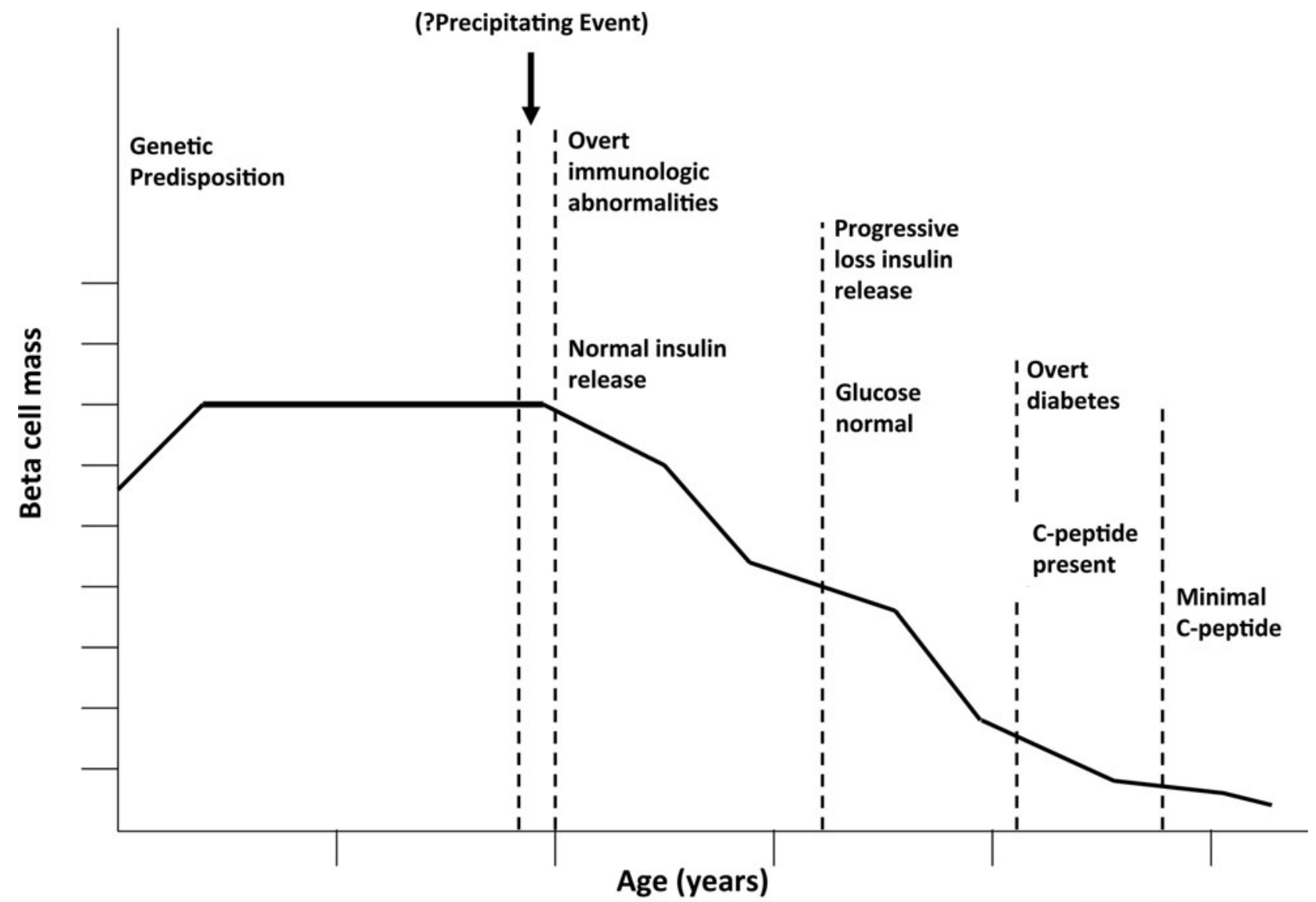

Eisenbarth 2012

FIG. 2. Updated scheme depicting a model of the stages of type 1 diabetes as a chronic progressive autoimmune disease, with variation in the rate of $\beta$-cell destruction during progression to hyperglycemia. Again, the $x$-axis is without a specific time scale as the rate of progress of the disease may be quite variable. Modified from Eisenbarth. ${ }^{5}$ Reprinted from Endocrine Practice, Vol 18, Eisenbarth GS: Prevention of type 1A diabetes mellitus, pp 745-749, 2012, with permission from the American Association of Clinical Endocrinologists.

standardized $^{24}$ ) or an abnormal glucose level but not one indicating diabetes during an oral glucose tolerance test (OGTT) and not have the protective HLA DQB1*0602. ${ }^{25}$ Based on these criteria, subjects enrolled in the DPT-1 parenteral insulin trial had a projected 5 -year risk of T1D of at least $50 \%$. The study screened 84,228 relatives of people with T1D, with $3.7 \%$ being positive for ICA on initial screening. The study randomized 339 subjects-the experimental group to receive twice-daily injections of human ultralente insulin (total daily dose of 0.25 units / $\mathrm{kg}$ ), plus annual 4-day infusions of intravenous insulin, whereas the control group had "close observation." 22 Both groups underwent an OGTT every 6 months. After a median follow-up of 3.7 years, the cumulative incidence of T1D was similar in the two groups (relative risk in the intervention group compared with the observation group, 0.96), a disappointing result. It should be noted that the observed 5-year risk of T1D was $65 \%$, thus validating the prediction criteria, which, as noted, were based in large part on George's concepts.

A subsequent Belgian study, which used prandial insulin rather than basal insulin, in relatives at risk of T1D also failed to show a beneficial effect on delaying progression to T1D. ${ }^{26}$

Meanwhile, it was recognized that while screening for the DPT-1 parenteral insulin trial, which required enrollees have a projected 5 -year risk of T1D of at least $50 \%$, there would be identified a cohort of individuals still at modestly high risk of T1D, but not a $50 \%$ projected risk. An important study that George had conducted together with Howard Weiner and colleagues had demonstrated in non-obese diabetic (NOD) mice (an animal model of T1D) that oral insulin could prevent the development of T1D. ${ }^{27}$ Even more powerful was the finding that splenocytes from NOD mice that had received oral insulin prevented the adoptive transfer of T1D in mice that concomitantly received splenocytes from mice with diabetes. ${ }^{27}$

These observations led to the DPT-1 Steering Committee electing to conduct a second concomitant study evaluating the use of oral insulin in relatives with a projected 5-year risk of T1D of $25-50 \% .^{28}$ That risk was based on subjects screening positive for ICA, also having insulin autoantibodies (IAA) and having "intact" FPIR on IVGTT and normal OGTT. The study screened a total of 103,391 relatives of people with T1D. Ultimately, 372 met the inclusion criteria and were randomized to receive oral insulin $(7.5 \mathrm{mg} /$ day) or matched placebo. Both groups underwent an OGTT every 6 months. After a median follow-up of 4.3 years, the cumulative incidence of T1D was similar in the two groups (hazard ratio in the oral insulin group compared with the placebo group, 0.76; $P=0.189$ ), another disappointing result. ${ }^{28}$ Yet, a post hoc hypothesis-generating analysis showed that there was a 
suggestion of a beneficial effect in enrollees who had on two occasions at baseline IAA levels of at least $80 \mathrm{nU} / \mathrm{mL}$. In such individuals ( $n=263$ of the 372 subjects randomized), the annualized diabetes rate was $6.2 \%$ with oral insulin and $10.4 \%$ with placebo (hazard ratio in the oral insulin group compared with the placebo group, $0.566 ; P=0.015)$. That subgroup was analyzed because it represented the initial IAA level required for enrollment. Unfortunately, enrollment rate was slower than projected, so the unfortunate decision (in hindsight) was made to reduce the level of IAA required for enrollment to $39 \mathrm{nU} / \mathrm{mL}$ (3 SD above the mean of controls without diabetes, whereas $80 \mathrm{nU} / \mathrm{mL}$ was $5 \mathrm{SD}$ above the mean of controls without diabetes).

Treatment was stopped in the DPT-1 oral insulin trial in 2003. In an effort to determine long-term outcome of the study, a telephone survey was conducted in 2009 to ascertain whether T1D had been diagnosed, and, if not, an OGTT, $\mathrm{HbA} 1 \mathrm{c}$, and autoantibody levels were obtained on subjects who agreed to participate. ${ }^{29}$ Overall, the oral insulin treatment effect in individuals with confirmed IAA of at least $80 \mathrm{nU} / \mathrm{mL}$ seemed to be sustained; yet, once treatment was stopped, the rate of developing T1D in the previous oral insulin group increased to that in the placebo group.

Given the results seen in the post hoc analysis of the DPT-1 oral insulin trial, Type 1 Diabetes TrialNet, ${ }^{30}$ an NIDDKsponsored clinical trials consortium that basically succeeded DPT-1, has elected to conduct another oral insulin prevention trial, with the expectation of replicating the outcome seen in the post hoc analysis of the DPT-1 oral insulin trial. ${ }^{30,31}$

Meanwhile, George continued to promote the concept that antigen-based therapies would be the safest and most specific way of dealing with immune modulation in T1D. ${ }^{32}$ Based on studies in NOD mice, ${ }^{33}$ he championed the concept that an altered peptide ligand, specifically a modification of the amino acid sequence of the peptides spanning positions 9-23 on the B-chain of insulin (B9-23), might modify the course of the disease. A study with a B9-23 altered peptide ligand was undertaken in recent-onset T1D but failed to show an effect on residual $\beta$-cell function. ${ }^{34}$

Another antigen-based approach is the use of a plasmid DNA vaccine encoding mouse pro-insulin. ${ }^{35}$ George participated in a mouse study suggesting the potential utility of this approach in T1D. ${ }^{36}$ Yet, the 1-year results of a clinical trial with a plasmid DNA vaccine encoding human pro-insulin in patients with T1D gave mixed results. ${ }^{37}$ The authors of the abstract asserted that there might be some associated preservation of $\beta$-cell function, but the data were not completely convincing. ${ }^{37}$ However, the plasmid DNA vaccine was well tolerated.

Unfortunately, several other antigen-based therapies also have not met with success. Nasal insulin was studied in the Type 1 Diabetes Prediction and Prevention Study (DIPP), which was conducted in Finland. ${ }^{38}$ The DIPP group screened 116,720 newborns from the general population for high-risk HLA-DQB1 susceptibility alleles, followed up 10,577 prospectively, and, after at least two diabetes autoantibodies were confirmed, eventually enrolled 224 who were randomized to receive either intranasal insulin ( 1 unit $/ \mathrm{kg}$ of body weight daily) or placebo. The rate of progression to T1D was the same in the nasal insulin group and the placebo group. ${ }^{38}$

Intranasal insulin has also been studied in Australia. The first trial established safety of the approach. ${ }^{39}$ A subsequent trial showed potential immunologic effect by demonstrating that the interferon- $\gamma$ response of blood T-cells to proinsulin was suppressed after nasal insulin. ${ }^{40} \mathrm{~A}$ full-scale trial is now being recruited. ${ }^{41}$

Also, currently underway is another study motivated by George-the PrePoint study. ${ }^{42}$ This is a primary prevention pilot study evaluating oral or nasal insulin in very high-risk children with genetic markers, to determine whether this might prevent the emergence of islet autoantibodies.

Another insulin-based approach is the use of pro-insulin peptides as immunotherapeutic vaccines. ${ }^{43}$ To date, only a Phase 1 safety study has been reported, but further studies are underway.

Another antigen that has been evaluated in several trials is glutamic acid decarboxylase (GAD). In recent-onset T1D, several trials using a GAD-alum vaccine have been conducted. A pilot study looked promising, ${ }^{44}$ but three larger trials failed to show a benefit on preserving residual $\beta$-cell function. ${ }^{45-47}$ A randomized controlled prevention study is currently taking place in Sweden, in which 50 children with at least two diabetes autoantibodies, including anti-GAD, have been enrolled. ${ }^{48}$ Also underway is a study in recent-onset T1D combining GAD vaccine, vitamin D, and ibuprofen. ${ }^{49}$

In his 2009 Banting Lecture to the American Diabetes Association, George described the importance of the "trimolecular complex" of insulin peptide being presented by major histocompatibility complex (MHC) class II to a specific T-cell receptor (TCR) V-alpha. ${ }^{50} \mathrm{He}$ focused on work on this complex from then until the time of his death, asserting that the primary trimolecular complex was a clearer therapeutic target for interdicting T1D. ${ }^{51}$ Thus, he and his colleagues have explored several ways of impacting the T1D disease process in NOD mice via interference with the trimolecular complex. One approach is vaccination with a mutated recombinant insulin peptide-MHC complex, which delayed development of autoantibodies and of diabetes in NOD mice. ${ }^{52}$ A second approach has involved a structure-based approach to identify small molecules that can either enhance or inhibit specific TCR signaling in the presence of target peptides. ${ }^{53}$ The latter approach identified glyphosine as a molecule that alters insulin peptide presentation to TCR and prevents diabetes in NOD mice. ${ }^{53}$ Further studies are in progress to identify small molecules that might be tested in human clinical trials.

Although mostly interested in antigen-based therapies, George also served as a member of the Steering Committee of Type 1 Diabetes TrialNet $^{30}$ and of the Network Steering Committee of the Immune Tolerance Network, ${ }^{54,55}$ both of which have been conducting trials in T1D with various immunomodulatory approaches. Studies have also been conducted outside of these networks.

In recent-onset T1D, to date there have been three approaches that have shown promise.

Anti-CD3 monoclonal antibodies selectively deplete pathogenic T-lymphocytes while preserving regulatory T-lymphocytes. ${ }^{56}$ In studies with two different anti-CD3 monoclonal antibodies, short treatment courses of 14 or 6 days in recent-onset T1D have shown preservation of residual $\beta$-cell function for several years, ${ }^{57-60}$ and another study has shown beneficial effect even when treatment has commenced beyond the initial period after diagnosis. ${ }^{61}$ Unfortunately, the anti-CD3 landscape has become confused because of failure of large Phase 3 clinical trials to meet their primary efficacy 
outcome measure. ${ }^{62,63}$ It has been highly debated whether the Phase 3 trials were appropriately designed. ${ }^{64}$ Thus, it is likely premature to abandon anti-CD3 approaches. Indeed, antiCD3 is being pursued by TrialNet as a therapy to prevent progression from altered glucose tolerance to clinical T1D. ${ }^{65}$

The anti-CD20 monoclonal antibody rituximab depletes Blymphocytes, which may have a role in facilitating activation of T-lymphocytes. ${ }^{66}$ Rituximab, given in recent-onset T1D as weekly infusions for 1 month, compared with placebo preserved residual $\beta$-cell function for 2 years. ${ }^{67,68}$

Abatacept (CTLA4-Ig) is a "second signal" co-stimulation blocker that prevents activation of T-lymphocytes. ${ }^{69}$ Given monthly over 2 years, it also preserved residual $\beta$-cell function in recent-onset T1D. ${ }^{70}$ That effect was sustained for 1 year following cessation of therapy. ${ }^{71}$

All three of these approaches that showed beneficial effects on residual $\beta$-cell function-anti-CD3, anti-CD20, and costimulation blockade-resulted in only transient benefit, as subsequent to initial improvement there was a progressive decline in $\beta$-cell function parallel to that seen in the respective placebo groups. ${ }^{57,58,67,70}$

Several other interventions-mycophenolate mofetil with or without concomitant dacluzimab, ${ }^{72}$ anti-interleukin- $1 \beta$ blockade with either the monoclonal antibody canikinumab or the interleukin- $1 \beta$ receptor anatagonist anakinra, ${ }^{73}$ or the Tcell-depleting drug thymoglobulin ${ }^{74}$ _failed to show beneficial effect on preservation of residual $\beta$-cell function.

In a small uncontrolled pilot study in recent-onset T1D, the combination of cyclophosphamide, high-dose thymoglobulin, and granulocyte colony-stimulating factor, together with rescue therapy of autologous human bone marrow transplantation, had an apparently beneficial effect as evidenced by cessation of insulin therapy in the majority of patients treated. ${ }^{75-77}$ A pilot study is currently underway to study this type of approach further, but with a milder combination: low-dose thymoglobulin plus granulocyte colony-stimulating factor. ${ }^{78}$

Several other studies are currently underway or being planned. It is our bias that combination therapy, involving several pathways, will be required to effectively intervene and sustain residual $\beta$-cell function for a protracted period of time. ${ }^{79}$ It was George's hope that others would carry on to achieve what he did not live to see-namely, the prevention and reversal of T1D. Fortunately, George's legacy includes a large number of former Fellows and trainees that he inspired to work in the field of immunopathogenesis and immunotherapy of T1D. They are likely to achieve this goal for him. To do so would be quite fitting, as George was an extraordinary mentor who demonstrated an incredible willingness to collaborate, to share data, to offer help to anyone in the field. He always had an air of excitement, like a young boy, thrilled to see the field advance. He will be missed, but we who continue to work in the field will fulfill his goal. Of that, we are certain.

\section{Author Disclosure Statement}

No competing financial interests exist.

\section{References}

1. Bottazzo GF, Florin-Christensen A, Doniach D: Islet-cell antibodies in diabetes mellitus with autoimmune polyendocrine deficiencies. Lancet 1974;304:1279-1283.
2. Nerup J, Platz P, Andersen OO, Christy M, Lyngsoe J, Poulsen JE, Ryder LP, Nielsen LS, Thomsen M, Svejgaard A: HL-A antigens and diabetes mellitus. Lancet 1974;304:864-866.

3. Eisenbarth GS: Type I diabetes mellitus. A chronic autoimmune disease. N Engl J Med 1986;314:1360-1368.

4. Atkinson MA, Eisenbarth GS: Type 1 diabetes: new perspectives on disease pathogenesis and treatment. Lancet 2001;358:221-229.

5. Eisenbarth GS: Prevention of type 1A diabetes mellitus. Endocr Pract 2012;18:745-749.

6. Atkinson MA, Eisenbarth GS, Michels A: Type 1 diabetes-a season of change for concepts regarding the epidemiology, pathogenesis, treatment and prospects for disease attenuation. Lancet 2013 (in press).

7. Skyler JS: Immune intervention studies in insulin-dependent diabetes mellitus. Diabetes Metab Rev 1987;3:1017-1035.

8. Skyler JS, Marks JB: Immune intervention in type I diabetes mellitus. Diabetes Rev 1993;1:15-42.

9. Skyler JS; Type 1 Diabetes TrialNet Study Group: Update on worldwide efforts to prevent type 1 diabetes. Ann N Y Acad Sci 2008;1150:190-196.

10. Skyler JS: Primary and secondary prevention of type 1 diabetes. Diabet Med 2013;30:161-169.

11. Eisenbarth GS, Srikanta S, Jackson RA, Rabinowe SL, Dolinar R, Haynes BF, Morris MA: Anti-thymocyte globulin and prednisone immunotherapy of recent onset type I diabetes mellitus. Diabetes Res 1985;2:271-276.

12. Skyler JS, Lorenz TJ, Schwartz S, Eisenbarth GS, Einhorn D, Palmer JP, Marks JB, Greenbaum C, Saria EA, Byers V; CD5 Diabetes Project Team: Effects of an anti-CD5 immunoconjugate (CD5-Plus ${ }^{\mathrm{TM}}$ ) in recent onset type I diabetes mellitus-a preliminary investigation. J Diabetes Complications 1993;7:224-232.

13. Eisenbarth GS, Srikanta S, Rabinowe SL, Jackson RA, Ganda OP, Soeldner JS: Restoration of first phase insulin secretion by daily prednisone in two islet cell antibody positive nondiabetic individuals. Transplant Proc 1986;18:805-808.

14. Herskowitz RD, Jackson RA, Soeldner JS, Eisenbarth GS: Pilot trial to prevent Type I diabetes: progression to overt IDDM despite oral nicotinamide. J Autoimmun 1989;2:733-737.

15. European Nicotinamide Diabetes Intervention Trial (ENDIT) Group: European Nicotinamide Diabetes Intervention Trial (ENDIT): a randomized controlled trial of intervention before the onset of type 1 diabetes. Lancet 2004;363:925-931.

16. Feutren G, Assan R, Karsenty G, Du Rostu H, Sirmai J, Papoz L, Vialettes B, Vexiau P, Rodier M, Lallemand A, Bach JF; Cyclosporin/Diabetes French Study Group: Cyclosporin increases the rate and length of remissions in insulin dependent diabetes of recent onset. Results of a multicentre double-blind trial. Lancet 1986;328:119-124.

17. The Canadian-European Randomized Control Trial Group: Cyclosporin-induced remission of IDDM after early intervention. Association of $1 \mathrm{yr}$ of cyclosporin treatment with enhanced insulin secretion. Diabetes 1988;37:1574-1582.

18. Carel JC, Boitard C, Eisenbarth G, Bach JF, Bougneres PF: Cyclosporine delays but does not prevent clinical onset in glucose intolerant pre-type 1 diabetic children. J Autoimmun 1996;9:739-745.

19. Keller RJ, Eisenbarth GS, Jackson RA: Insulin prophylaxis in individuals at high risk of type I diabetes. Lancet 1993;341:927-928.

20. Ziegler A, Bachmann W, Rabl W: Prophylactic insulin treatment in relatives at high risk for type 1 diabetes. Diabetes Metab Rev 1993;9:289-293. 
21. Fuchtenbusch M, Rabl W, Grassl B, Bachmann W, Standl E, Ziegler AG: Delay of type I diabetes in high risk, first degree relatives by parenteral antigen administration: the Schwabing Insulin Prophylaxis Pilot Trial. Diabetologia 1998;41:536-541.

22. Diabetes Prevention Trial-Type 1 Study Group: Effects of insulin in relatives of patients with type 1 diabetes mellitus. N Engl J Med 2002;346:1685-1691.

23. Eisenbarth GS, Verge CF, Allen H, Rewers MJ: Perspectives in diabetes: the design of trials for the prevention of IDDM. Diabetes 1993;42:941-947.

24. Bingley PJ, Colman P, Eisenbarth GS, Jackson RA, McCulloch DK, Riley WJ, Gale EA: Standardization of IVGTT to predict IDDM. Diabetes Care 1992;15:1313-1316.

25. Pugliese A, Gianani R, Moromisato R, Awdeh ZL, Alper CA, Erlich HA, Jackson RA, Eisenbarth GS: HLA-DQB1*0602 is associated with dominant protection from diabetes even among islet cell antibody-positive first-degree relatives of patients with IDDM. Diabetes 1995;44:608-613.

26. Vandemeulebroucke E, Gorus F, Decochez K, Weets I, Keymeulen B, De Block C, Tits J, Pipeleers D, Mathieu C; The Belgian Diabetes Registry: Insulin treatment in IA-2Apositive relatives of type 1 diabetic patients. Diabetes Metab 2009;35:319-327.

27. Zhang ZJ, Davidson L, Eisenbarth G, Weiner HL: Suppression of diabetes in nonobese diabetic mice by oral administration of porcine insulin. Proc Natl Acad Sci U S A 1991; 88:10252-10256.

28. Skyler JS, Krischer JP, Wolfsdorf J, Cowie C, Palmer JP, Greenbaum C, Cuthbertson D, Rafkin-Mervis LE, Chase HP, Leschek E; Diabetes Prevention Trial-Type 1 Diabetes Study Group: Effects of oral insulin in relatives of patients with type 1 diabetes mellitus. Diabetes Care 2005;28:1068-1076.

29. Vehik K, Cuthbertson D, Ruhlig H, Schatz DA, Peakman M, Krischer JP; DPT-1 and TrialNet Study Groups: Long-term outcome of individuals treated with oral insulin: diabetes prevention trial-type 1 (DPT-1) oral insulin trial. Diabetes Care 2011;34:1585-1590.

30. Skyler JS, Greenbaum CJ, Lachin JM, Leschek E, RafkinMervis L, Savage P, Spain L; Type 1 Diabetes TrialNet Study Group: Type 1 Diabetes TrialNet-an international collaborative clinical trials network. Ann N Y Acad Sci 2008; 1150:14-24.

31. Oral Insulin for Prevention of Diabetes in Relatives at Risk for Type 1 Diabetes Mellitus. ClinicalTrials.gov Identifier NCT00419562. www.ClinicalTrials.gov/ (accessed March 30, 2013)

32. Peakman $M$, von Herrath $M$ : Antigen-specific immunotherapy for type 1 diabetes: maximizing the potential. Diabetes 2010;59:2087-2093.

33. Kobayashi M, Abiru N, Arakawa T, Fukushima K, Zhou H, Kawasaki E, Yamasaki H, Liu E, Miao D, Wong FS, Eisenbarth GS, Eguchi K: Altered B:9-23 insulin, when administered intranasally with cholera toxin adjuvant, suppresses the expression of insulin autoantibodies and prevents diabetes. J Immunol 2007;179:2082-2088.

34. Walter M, Philotheou A, Bonnici F, Ziegler AG, Jimenez R; NBI-6024 Study Group: No effect of the altered peptide ligand NBI-6024 on beta-cell residual function and insulin needs in new-onset type 1 diabetes. Diabetes Care 2009; 32:2036-2040.

35. Garren H: DNA vaccines for autoimmune diseases. Expert Rev Vaccines 2009;8:1195-1203.

36. Solvason N, Lou YP, Peters W, Evans E, Martinez J, Ramirez U, Ocampo A, Yun R, Ahmad S, Liu E, Yu L, Eisenbarth G,
Leviten M, Steinman L, Garren H: Improved efficacy of a tolerizing DNA vaccine for reversal of hyperglycemia through enhancement of gene expression and localization to intracellular sites. J Immunol 2008;181:8298-8307.

37. Gottlieb P, Colman PG, Solvason N, Otto K, Roep B, Harrison LC, Eisenbarth G, Robinson W, Utz PJ, Steinman L, Garren H, Quan J: One-year results from a Phase 1/2 clinical trial of BHT-3021, a DNA plasmid vaccine for type 1 diabetes (T1D) [abstract]. Diabetes 2010;53(Suppl 1):66-OR.

38. Näntö-Salonen K, Kupila A, Simell S, Siljander H, Salonsaari T, Hekkala A, Korhonen S, Erkkola R, Sipilä JI, Haavisto L, Siltala M, Tuominen J, Hakalax J, Hyöty H, Ilonen J, Veijola R, Simell T, Knip M, Simell O: Nasal insulin to prevent type 1 diabetes in children with HLA genotypes and autoantibodies conferring increased risk of disease: a doubleblind, randomised controlled trial. Lancet 2008;372:1746-1755.

39. Harrison LC, Honeyman MC, Steele CE, Stone NL, Sarugeri E, Bonafacio E, Couper JJ, Colman PG: Pancreatic beta-cell function and immune responses to insulin after administration of intranasal insulin to humans at risk for type 1 diabetes. Diabetes Care 2004;27:2348-2355.

40. Fourlanos S, Perry C, Gellert SA, Martinuzzi E, Mallone R, Butler J, Colman PG, Leonard C: Evidence that nasal insulin induces immune tolerance to insulin in adults with autoimmune diabetes. Diabetes 2011;60:1237-1245.

41. Trial of Intranasal Insulin in Children and Young Adults at Risk of Type 1 Diabetes (INIT II). ClinicalTrials.gov Identifier NCT00336674. www.ClinicalTrials.gov/ (accessed March 30, 2013).

42. Achenbach $\mathrm{P}$, Barker J, Bonifacio E: Modulating the natural history of type 1 diabetes in children at high genetic risk by mucosal insulin immunization. Curr Diab Rep 2008;8:87-93.

43. Thrower SL, James L, Hall W, Green KM, Arif S, Allen JS, Van-Krinks C, Lozanoska-Ochser B, Marquesini L, Brown S, Wong FS, Dayan CM, Peakman M: Proinsulin peptide immunotherapy in type 1 diabetes: report of a first-in-man Phase I safety study. Clin Exp Immunol 2009;155:156-165.

44. Ludvigsson J, Faresjö M, Hjorth M, Axelsson S, Chéramy M, Pihl M, Vaarala O, Forsander G, Ivarsson S, Johansson C, Lindh A, Nilsson NO, Aman J, Ortqvist E, Zerhouni P, Casas R: GAD treatment and insulin secretion in recent-onset type 1 diabetes. N Engl J Med 2008;359:1909-1920.

45. Wherrett DK, Bundy B, Becker DJ, DiMeglio LA, Gitelman SE, Goland R, Gottlieb PA, Greenbaum CJ, Herold KC, Marks JB, Monzavi R, Moran A, Orban T, Raskin P, Rodriguez H, Russell WE, Schatz D, Wilson DM, Skyler JS; The Type 1 Diabetes TrialNet GAD Study Group: Antigenbased therapy with glutamic acid decarboxylase (GAD) vaccine in patients with recent-onset type 1 diabetes: a randomised double-blind trial. Lancet 2011;378:319-327.

46. Ludvigsson J, Krisky D, Casas R, Battelino T, Castaño L, Greening J, Kordonouri O, Otonkoski T, Pozzilli P, Robert JJ, Veeze HJ, Palmer J: GAD65 antigen therapy in recently diagnosed type 1 diabetes mellitus. N Engl J Med 2012; 366:433-442.

47. Diamyd Initiates Closure of US Phase III Study [press release]. June 23, 2011. www.diamyd.com/docs/pressClip .aspx? section $=$ investor\&ClipID $=584435$ (accessed March 30, 2013).

48. Diabetes Prevention-Immune Tolerance (DIAPREV-IT). ClinicalTrials.gov Identifier NCT01122446. www.ClinicalTrials .gov/ (accessed March 30, 2013).

49. DIABGAD—Trial to Preserve Insulin Secretion in Type 1 Diabetes Using GAD-Alum (Diamyd) in Combination with 
Vitamin D and Ibuprofen. ClinicalTrials.gov Identifier NCT01785108. www.ClinicalTrials.gov/ (accessed March 30, 2013).

50. Eisenbarth GS: Banting Lecture 2009: an unfinished journey: molecular pathogenesis to prevention of type 1A diabetes. Diabetes 2010;59:759-774.

51. Sosinowski T, Eisenbarth GS: Type 1 diabetes: primary antigen/peptide/register/trimolecular complex. Immunol Res 2013;55:270-276.

52. Zhang L, Stadinski BD, Michels A, Kappler JW, Eisenbarth GS: Immunization with an insulin peptide-MHC complex to prevent type 1 diabetes of NOD mice. Diabetes Metab Res Rev 2011;27:784-789.

53. Michels AW, Ostrov DA, Zhang L, Nakayama M, Fuse M, McDaniel K, Roep BO, Gottlieb PA, Atkinson MA, Eisenbarth GS: Structure-based selection of small molecules to alter allele-specific MHC class II antigen presentation. J Immunol 2011;187:5921-5930.

54. Bluestone JA, Matthews JB: The Immune Tolerance Network-an NIH/JDF-supported initiative to bring tolerance research into the clinic: a major new resource for clinical immunologists. Clin Immunol 2000;96:171-173.

55. Bluestone JA, Auchincloss H, Nepom GT, Rotrosen D, St Clair EW, Turka LA: The Immune Tolerance Network at 10 years: tolerance research at the bedside. Nat Rev Immunol 2010;10:797-803.

56. Penaranda C, Tang Q, Bluestone JA: Anti-CD3 therapy promotes tolerance by selectively depleting pathogenic cells while preserving regulatory T cells. J Immunol 2011;187: 2015-2022.

57. Herold KC, Hagopian W, Auger JA, Poumian-Ruiz E, Taylor L, Donaldson D, Gitelman SE, Harlan DM, Xu D, Zivin RA, Bluestone JA: Anti-CD3 monoclonal antibody in new-onset type 1 diabetes mellitus. N Engl J Med 2002;346:1692-1698.

58. Herold KC, Gitelman SE, Masharani U, Hagopian W, Bisikirska B, Donaldson D, Rother K, Diamond B, Harlan DM, Bluestone JA: A single course of anti-CD3 monoclonal antibody hOKT3gamma1(Ala-Ala) results in improvement in Cpeptide responses and clinical parameters for at least 2 years after onset of type 1 diabetes. Diabetes 2005;54:1763-1769.

59. Keymeulen B, Vandemeulebroucke E, Ziegler AG, Mathieu C, Kaufman L, Hale G, Gorus F, Goldman M, Walter M, Candon S, Schandene L, Crenier L, De Block C, Seigneurin JM, De Pauw P, Pierard D, Weets I, Rebello P, Bird P, Berrie E, Frewin M, Waldmann H, Bach JF, Pipeleers D, Chatenoud L: Insulin needs after CD3-antibody therapy in new-onset type 1 diabetes. N Engl J Med 2005;352:2598-2608.

60. Keymeulen B, Walter M, Mathieu C, Kaufman L, Gorus F, Hilbrands R, Vandemeulebroucke E, Van de Velde U, Crenier L, De Block C, Candon S, Waldmann H, Ziegler AG, Chatenoud L, Pipeleers D: Four-year metabolic outcome of a randomised controlled CD3-antibody trial in recent-onset type 1 diabetic patients depends on their age and baseline residual beta cell mass. Diabetologia 2010;53:614-623.

61. Herold KC, Gitelman SE, Willi SM, Gottlieb PA, WaldronLynch F, Devine L, Sherr J, Rosenthal SM, Adi S, Jalaludin MY, Michels AW, Dziura J, Bluestone JA: Teplizumab treatment may improve C-peptide responses in participants with type 1 diabetes after the new-onset period: a randomised controlled trial. Diabetologia 2013;56:391-400.

62. Sherry N, Hagopian W, Ludvigsson J, Jain SM, Wahlen J, Ferry RJ Jr, Bode B, Aronoff S, Holland C, Carlin D, King KL, Wilder RL, Pillemer S, Bonvini E, Johnson S, Stein KE, Koenig S, Herold KC, Daifotis AG; Protégé Trial In- vestigators: Teplizumab for treatment of type 1 diabetes (Protégé Study): 1-year results from a randomised, placebocontrolled trial. Lancet 2011;378:487-497.

63. Trial of Otelixizumab for Adults with Newly Diagnosed Type 1 Diabetes Mellitus (Autoimmune): DEFEND-1. ClinicalTrials.gov Identifier NCT00678886. www.ClinicalTrials.gov/ (accessed March 30, 2013).

64. Staeva TP, Chatenoud L, Insel R, Atkinson MA: Recent lessons learned from prevention and recent-onset type 1 diabetes immunotherapy trials. Diabetes 2013;62:9-17.

65. Teplizumab for Prevention of Type 1 Diabetes in Relatives "At-Risk." ClinicalTrials.gov Identifier NCT01030861. www .ClinicalTrials.gov/ (accessed March 30, 2013).

66. Peter HH, Warnatz K: Molecules involved in T-B costimulation and B cell homeostasis: possible targets for an immunological intervention in autoimmunity. Expert Opin Biol Ther 2005;5(Suppl 1):S61-S71.

67. Pescovitz MD, Greenbaum CJ, Krause-Steinrauf H, Becker DJ, Gitelman SE, Goland R, Gottlieb PA, Marks JB, McGee PF, Moran AM, Raskin P, Rodriguez H, Schatz DA, Wherrett D, Wilson DM, Lachin JM, Skyler JS; The Type 1 Diabetes TrialNet Anti-CD20 Study Group: Rituximab, B-lymphocyte depletion and preservation of beta-cell function. N Engl J Med 2009;361:2143-2152.

68. Pescovitz MD, Greenbaum CJ, Bundy BN, Becker DJ, Gitelman SE, Goland R, Gottlieb PA, Marks JB, McGee PF, Moran AM, Raskin P, Rodriguez H, Schatz DA, Wherrett D, Wilson DM, Skyler JS,; The Type 1 Diabetes TrialNet AntiCD20 Study Group: Preservation of beta-cell function by Blymphocyte depletion with rituximab: sustained effects. Submitted for publication.

69. Marelli-Berg FM, Okkenhaug K, Mirenda V: A two-signal model for $\mathrm{T}$ cell trafficking. Trends Immunol 2007;28: 267-273.

70. Orban T, Bundy B, Becker DJ, DiMeglio LA, Gitelman SE, Goland R, Gottlieb PA, Greenbaum CJ, Marks JB, Monzavi R, Moran A, Raskin P, Rodriguez H, Russell WE, Schatz D, Wherrett D, Wilson DM, Skyler JS; The Type 1 Diabetes TrialNet Abatacept Study Group: Co-stimulation modulation with abatacept in patients with recent-onset type $1 \mathrm{di}-$ abetes: a randomised double-blind, placebo-controlled trial. Lancet 2011;378:412-419.

71. Orban T, Bundy B, Becker DJ, DiMeglio LA, Gitelman SE, Goland R, Gottlieb PA, Greenbaum CJ, Marks JB, Monzavi R, Moran A, Peakman M, Raskin P, Rodriguez H, Russell WE, Schatz D, Wherrett D, Wilson DM, Skyler JS; The Type 1 Diabetes TrialNet Abatacept Study Group: Co-stimulation modulation with abatacept in patients with recent-onset type 1 diabetes: follow-up one year after cessation of treatment. Submitted for publication.

72. Gottlieb PA, Quinlan S, Krause-Steinrauf H, Greenbaum CJ, Wilson DM, Rodriguez H, Schatz DA, Moran AM, Lachin JM, Skyler J; the Type 1 Diabetes TrialNet MMF/DZB Study Group: Failure to preserve beta-cell function with mycophenolate mofetil and daclizumab combined therapy in patients with new onset type 1 diabetes. Diabetes Care 2010;33:826-832.

73. Moran A, Bundy B, Becker DJ, DiMeglio LA, Gitelman SE, Goland R, Greenbaum CJ, Herold KC, Marks JB, Raskin P, Sanda S, Schatz D, Wherrett D, Wilson DM, Skyler JS; the Type 1 Diabetes TrialNet Canakinumab Study Group; Pickersgill L, de Koning E, Ziegler A-G, Böehm B, Badenhoop K, Schloot N, Bak JF, Pozzilli P, Mauricio D, Donath MY, Castaño L, Wägner A, Lervang HH, Perrild H, 
Mandrup-Poulsen T; the AIDA Study Group: Interleukin-1 antagonism in type 1 diabetes of recent onset: two multicenter, randomized double-masked, placebo-controlled trials. Lancet 2013 Epub April 5. doi: 10.1016/S01406736(13)60023-9.

74. Gitelman SE, Fisher LK, Gottlieb PA, Gottschalk M, Moore WV, Moran A, Rigby MR, Willi SM, Keyes-Elstein L, Pinckney A, Ding L, Ehlers MR; START Study Team: Effect of anti-thymocyte globulin (ATG) on preserving beta cell function in new-onset type 1 diabetes. Diabetologia 2012;55(Suppl 1):S191-192.

75. Voltarelli JC, Couri CE, Stracieri AB, Oliveira MC, Moraes DA, Pieroni F, Coutinho M, Malmegrim KC, Foss-Freitas MC, Simões BP, Foss MC, Squiers E, Burt RK: Autologous nonmyeloablative hematopoietic stem cell transplantation in newly diagnosed type 1 diabetes mellitus. JAMA 2007;297: 1568-1576.

76. Couri CE, Oliveira MC, Stracieri AB, Moraes DA, Pieroni F, Barros GM, Madeira MI, Malmegrim KC, Foss-Freitas MC, Simões BP, Martinez EZ, Foss MC, Burt RK, Voltarelli JC: Cpeptide levels and insulin independence following autolo- gous nonmyeloablative hematopoietic stem cell transplantation in newly diagnosed type 1 diabetes mellitus. JAMA 2009;301:1573-1579.

77. Voltarelli JC, Martinez ED, Burt RK: Autologous nonmyeloablative hematopoietic stem cell transplantation in newly diagnosed type 1 diabetes mellitus. Author's reply. JAMA 2009;302:624-625.

78. Reversing Type 1 Diabetes After It Is Established. ClinicalTrials.gov Identifier NCT01106157. www.ClinicalTrials .gov/ (accessed March 30, 2013).

79. Skyler JS, Ricordi C: Stopping type 1 diabetes: attempts to prevent or cure type 1 diabetes in man. Diabetes 2011;60:1-8.

Address correspondence to: Jay S. Skyler, MD, MACP

Diabetes Research Institute University of Miami Miller School of Medicine 1450 NW $10^{\text {th }}$ Avenue Miami, FL 33136

E-mail: jskyler@miami.ed 